\title{
3. Belgium: Is strong social concertation a driver of upward social convergence?
}

\author{
Ive Marx
}

\section{INTRODUCTION}

As one of the six original signatories to the Treaty of Rome, Belgium has been at the heart of the European project from the start. In that treaty, the founders of the European Economic Community expressed their determination to

lay the foundations of an ever closer union among the peoples of Europe, resolved to ensure the economic and social progress of their countries by common action to eliminate the barriers which divide Europe, affirming as the essential objective of their efforts the constant improvements of the living and working conditions of their peoples. (Treaty of Rome)

The founding fathers anticipated that European economic integration would contribute to the development of thriving national welfare states without the need for supranational steering or coordination. They hoped and assumed that (upward) convergence would occur automatically and in step. European integration would simultaneously drive economic and social progress, both within countries, through the incremental development of the welfare states, and between countries, through upward convergence across the European Union (EU).

The Ohlin report, published by the International Labour Organisation in 1956, provided the intellectual foundation for the belief that economic integration to the benefit of all could happen without social harmonisation. Bertil Ohlin and colleagues posited that differences in labour costs between the countries concerned were so closely related to differences in productivity that free trade would not cause downward pressure on wages.

It may well be argued that this view has, by and large, been vindicated. In parallel with the process of European integration, national welfare states have expanded, not contracted. Successive enlargements of the European Community and the EU have invariably resulted in upward convergence. Concerns that EU enlargement and intensified free trade and movement within the single market would bring social dumping and downward convergence have largely proven to be wrong.

However, the sentiment in Europe currently is hardly one of joy and satisfaction. Social conditions in Europe leave much to be desired, especially after one of the deepest and most protracted recessions in modern history. That there has been no major downward convergence in labour standards or social rights in the absence of much supranational coordination of social standards is hardly a cause for celebration. Surely the founding fathers had higher hopes and ambitions. 
The European Pillar of Social Rights, launched in 2017, represents a new Commission flagship initiative to promote upwards social convergence across the EU. After a lengthy consultation period, the European Commission launched an ambitious proposal outlining 20 principles in April 2017. The key question remains whether these principles, which are not enforceable, will translate into meaningful social change. In that light, it is useful to gauge what has happened so far and how earlier European processes and initiatives have affected institutions, policies and outcomes.

The European Pillar of Social Rights is part of a marked shift in discourse at the European level. Responding to criticism that the EU had become too much of an economic project, EU Commission President Juncker declared in 2016 that the EU needs to be 'Triple A' on social issues.

As part of the same drive towards strengthening 'Social Europe', the European Commission has also started calling for a more substantial involvement of the social partners in EU policy- and law-making. That requires, in the eyes of the European Commission, a stronger emphasis on capacity-building among the national social partners.

In this context Belgium presents a particularly salient case in that it retains an exceptionally extensive and resilient social concertation model. Trade union membership and bargaining coverage remain high compared with other EU member states. This accompanies a deep-rooted and still robust tradition of multi-tiered bargaining on all aspects of working conditions. In addition to the many issues on which they have autonomy to negotiate and conclude collective agreements, social partners wield significant influence in shaping social and economic policy through their institutionalised advisory and governance roles.

Belgium's atypical trajectory on such issues as income inequality or middle-class stability can be plausibly linked to the country's remarkably resilient social concertation model (Kuypers and Marx 2016; Marx and Van Cant 2018). Belgium stands out in the rich world in that there has been less divergence than in many other places between the conventional measures of economic affluence, such as gross domestic product (GDP) per capita, and living standards. The benefits of economic growth appear to have been more equitably spread than in many other rich economies, where the rich have tended to gain disproportionately (Nolan 2018).

Belgium's extensive and robust social dialogue model has probably helped to contain inequality. However, despite low overall income inequality Belgian society is not as inclusive as it may appear from afar. Access to a good life is very strongly stratified. The major fault-line in Belgium is not between high- and low-waged workers, or between precarious and non-precarious workers, but between those with a job and those failing to gain access to the labour market. This could be understood, at least in part, in the context of the insider biases inherent in an extensive social concertation model like Belgium's.

The question, then, is what lessons the Belgian case may hold for other countries in Europe, for better and for worse. This chapter looks in greater depth at how Belgium's unique social corporatist model has contributed to economic and social outcomes compared with elsewhere in Europe, particularly the countries that resemble it most closely in terms of economic development and European integration. That is not to say that we claim to present definitive evidence of how social corporatism or industrial relations affect outcomes, particularly how it has contributed to any convergence trends. That would 
require a research design fundamentally different from the one country case study this chapter presents. What I offer is a plausible interpretation of observed trends in the context of Belgium's, in many respects, unique institutional context. This chapter is best read as a complement to other recent contributions that deal with social dialogue (Kuypers and Marx 2016; Marx and Van Cant 2018; Marx and Verbist 2018). However, to ensure that this chapter can be read on its own some of the same ground is inevitably covered again.

\section{INDUSTRIAL RELATIONS AS A FACTOR IN BELGIUM'S SOCIAL PROGRESS}

To ascertain how industrial relations have contributed to upward economic and social convergence, we start by sketching the main features of Belgium's industrial relations. Belgium has a dense, pluralistic industrial relations landscape, with major fault-lines running along sectoral, ideological and regional dimensions.

Workers in Belgium have organised themselves by economic sector rather than by profession. The sectoral unions, which are the real powerhouses of Belgian trade unionism, amalgamate at the federal level on the basis of the traditional ideological 'pillars' of Belgian society. The two largest union confederations are linked to the Christian and socialist movements, respectively, while the significantly smaller third union is linked to the liberal family.

Within their respective pillars, unions are part of a network of organisations such as mutual funds, financial institutions, political parties, schools and hospitals. At around 50 per cent, union membership remains relatively high in Belgium. Belgium's partial Ghent system is important in this context. While unemployment insurance is compulsory, trade unions retain a major role in the provision of benefits; therefore, Belgium is said to have a partial Ghent system. Notwithstanding the fact that union membership is not mandatory for the insured, the vital role of trade unions in the provision of unemployment benefits and the regular contact with union officials during spells of unemployment are said to strongly motivate workers to join unions (Van Rie et al. 2011).

The Belgian industrial relations landscape also features well-established employers' organisations, at federal and regional levels. On the workers' side, employers organise by sector as that is the main level of bargaining. Alongside these national and regional organisations there are a number of small and medium-sized enterprise confederations, interest groups, social profit confederations and other networks or platforms.

Trade unions and employers' organisations are firmly embedded in the institutional framework through multiple roles, including consultation, co-governance and bargaining.

Two important national negotiation and consultation bodies are in place: the National Labour Council (NLC) and the Central Economic Council (CEC), which advise the national authorities on labour and social security law and on general economic issues (for example, market conditions, expansion policy, taxation, inflation and competitiveness), respectively. Moreover, numerous other consulting socio-economic councils are in place at the regional, sectoral and firm levels.

Social partners are represented on the governing boards of social security institutes, vocational training (sectoral training funds) and labour market agencies. They also sit on governance and supervisory boards of numerous other bodies. 
Collective bargaining is the most consequential activity of the social partners, especially since nearly all collective agreements are made generally binding, greatly extending their impact and ensuring near full coverage of the workforce. Collective bargaining is hierarchical and takes place at three levels. A national cross-sectoral agreement provides a framework within which social partners negotiate at the sectoral level. In turn, the sectoral collective agreements set a framework for bargaining at the company level. Collective agreements concluded at a lower level cannot deviate for the worse from the agreements set at a higher level.

The social partners retain a very high degree of autonomy on wages and working conditions. On most matters there is a legal framework that sets out principles and limits, but within that framework the social partners usually have a significant degree of freedom. Bargaining on all these aspects of work occurs in a multi-tiered coordinated system. Representatives of the main employers' organisations and trade unions agree every two years on a national Interprofessional Agreement (IPA) which functions as a general framework for further negotiations and covers issues such as wages, social contributions and replacement incomes. Implementing the framework negotiated at the national level, social partners then bargain over different aspects of working conditions (for example, pay levels, classification schemes, working-time arrangements and training) at the intermediate sectoral level, which is in effect the most important level. There are some 170 so-called parity committees.

At the firm level there are several bodies. A works council has advisory competence on financial, economic, technical and social matters, and decides on issues such as educational leave and vacation dates. The Committee for Prevention and Protection at the Workplace oversees issues related to workers' health, safety and hygiene. The trade union delegation negotiates directly on working conditions with the employer and intervenes in any conflict the staff might have with the employer.

Having sketched the basic architecture of Belgium's industrial relations we now turn to outcomes.

\section{ECONOMIC GROWTH AND PROSPERITY AS DRIVERS OF CONVERGENCE}

Belgium is one of the EU's more affluent countries and certainly one of its most productive. In 2016 Belgium's per capita GDP stood at 118 per cent of the EU28 average, slightly down from 119 per cent in 2006, according to Eurostat statistics. Labour productivity per hour worked stood at 147 per cent of the EU28 average (down from 153 per cent in 2006).

Belgium, and particularly Flanders, has been economically important in Europe since the Middle Ages, thanks in part to plentiful deposits of coal and metal ores. In addition to its natural resources, the area is strategically located with respect to Europe's major markets. It has easy access to the capital and technology markets of Great Britain and the consumer markets of France.

Belgium was the first area in Europe to industrialise, after Britain, whose industrial structure it had come to resemble after the Second World War. Productivity growth lagged behind many other European countries during the first 15 years after the war. Cassiers et al. (1996) attribute this to the immediate post-war years being marked by a 
search for social peace and the protection of economic interests. Belgium was a founding member of the European Coal and Steel Community. From 1960 onwards productivity growth accelerated, especially in manufacturing industry. Cassiers et al. (1996) attribute this in part to a liberalisation of the economy prompted by Belgium's adherence to the European Community. This also brought an influx of foreign investment.

Belgium's limited home market has always meant a very strong dependence on foreign trade and hence a strong international orientation in matters of economic policy.

The Belgian industrial sector was particularly hard hit by the oil shocks and the economic downturns of the 1970s and 1980s. The share of industrial employment (including mining and construction) in total employment, which was still around 40 per cent in 1975 , fell rapidly in the years thereafter, reflecting major structural adjustments in the steel, coal and textile industries. During the 1980s, Belgium recorded the fourth largest percentage of job losses in manufacturing in the Organisation for Economic Co-operation and Development (OECD) area. By 1992, employment in industry represented less than 28 per cent of total employment (OECD 1997).

Since 1970, growth of GDP per capita in Belgium as well as in the EU has been on a declining trend. Since the beginning of the 1990s, the slowdown of economic growth has been caused by a decline in labour productivity growth, hours worked making a modest but positive contribution to growth.

Structural evolutions in the economy between 1970 and 2005 have also influenced productivity performance. The slowdown of labour productivity growth in Belgium is owing mainly to a decreasing manufacturing contribution (Biatour and Kegels 2008). Since 2000, market services have become the most important contributor to aggregate labour productivity growth. During 1970-2005, the main contributor of productivity gains in Belgian was capital deepening, especially information and communication technology (ICT) capital deepening in services, while in the EU as a whole and in the United States it was multi-factor productivity.

However, GDP and productivity growth are only part of the story when it comes to economic progress. Nolan et al. (2018) have shown that per capita GDP has, in many countries, risen faster than real household incomes, especially for those around the median and below. The size of that divergence varies a great deal. The United States is a very clear outlier in that GDP per capita has risen much more strongly than actual household living standards around the middle. Most of the gains have ended up at the top. Belgium lies at the other end of the spectrum. It is one of the countries where actual living standards have tracked GDP growth most closely; both having increased substantially. In addition, while the share of national income represented by wages and benefits - the labour share - has declined in nearly all OECD countries, this trend too has been far less obvious in Belgium (OECD 2012).

Marx and Verbist (2018) confirm that Belgian households experienced mild but steady increases across the income spectrum between 1985 and 2014, the period for which generally consistent survey data are available. It shows slightly higher growth in the bottom quintile than in the next four quintiles, where growth was nearly identical (Figure 3.1).

There were periods when living standards increased more for lower-income households, such as the period 1993-2000. The pre-crisis period covered by European Union Statistics on Income and Living Conditions (EU-SILC) (2003-08) was a period of relatively strong increases, especially for the bottom and the top quintiles. Living-standard growth has 


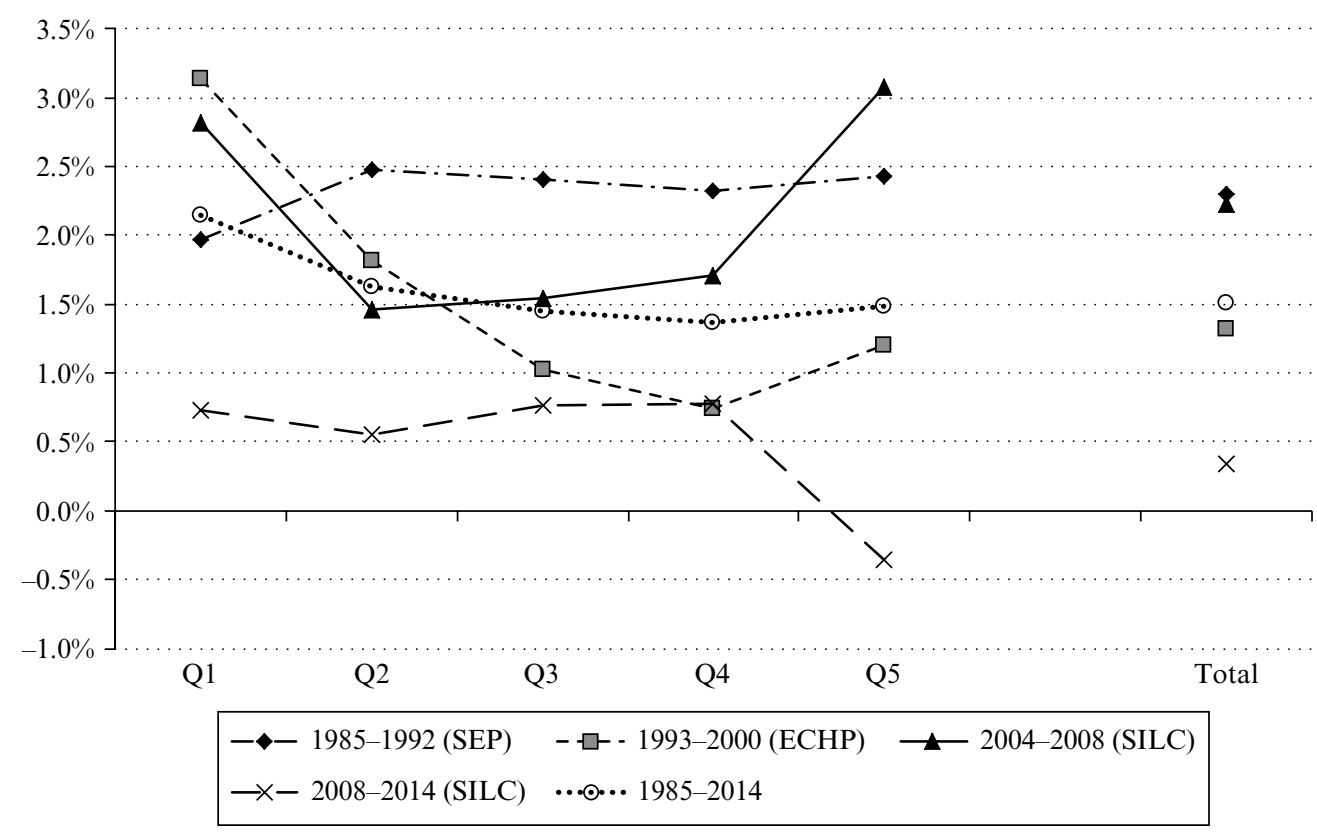

Note: The average growth rate for 1985-2014 is calculated as the weighted average of the annual growth rates of the different sub-periods. Total $=$ total population.

Source: Marx and Verbist (2018).

Figure 3.1 Annual growth rate of real equivalent disposable household income by quintile, total population, Belgium, 1985-2014

been far weaker since 2003, with even a slight drop for higher-income households. This broad picture of relatively equitably shared growth between 1985 and 2014 is also roughly consistent with the picture of stable overall income inequality, as captured by the (middleincome sensitive) GINI coefficient, shown in Chapter 2 and in other comparative studies of inequality (for example, OECD 2008, 2011; Nolan et al. 2014).

Earnings have been an important driver of income growth; in most periods covered here, household earnings increased relatively evenly across the income distribution. Benefits increased less than earnings in the first two periods but they were clearly propoor; that is, there were stronger increases for the bottom quintile than for the other quintiles. In the final two periods household benefit increases were more significant but they were also more evenly spread.

The major driver behind the trend in overall earnings is the share of earners, and especially the share of female earners. The share of male earners has been more stable overall. Average earnings grew steadily across the board, albeit stronger for men than for women, probably because the data do not allow us to control fully for hours worked. Increases in part-time and temporary work may therefore appear to depress wage growth. Data on real monthly earnings of full-time workers from the OECD database, which for Belgium is based on the structure of earnings survey, also show substantial wage increases at 
all percentile cut-offs. These data also have limitations in that they cover only full-time earners working in companies of a certain size.

Nevertheless, all the evidence we have suggests that there has been steady real-wage growth across the board, which has not happened everywhere. As documented in this volume and elsewhere, wage growth has been sluggish in a number of European countries, especially compared with productivity growth, and earnings inequality has tended to rise also. Concurrently, the share of labour in national income has tended to decline. Belgium has followed a different trajectory in every respect, warranting a closer look at what happened to wages.

\section{STRONG WAGE GROWTH ACROSS THE BOARD AS A DRIVER OF CONVERGENCE}

In many rich countries there has been downward pressure on the labour share during the past three decades. The trend started in the 1970s but the sharpest declines occurred from the early 1990s onwards. The financial crisis of 2008 temporarily reversed the longer-term decline, in part because earnings tend to be less volatile than profits during economic downturns. Following 2009, the downward trend has resumed in most rich countries (OECD 2015b).

Several explanations have been put forward, including structural transformations in national economies involving a shift from labour-intensive to more capital-intensive sectors, globalisation and outsourcing, skill-biased and capital-augmenting technological change, privatisation of state-owned enterprises and the increased role of financial markets.

While the pattern of declining labour shares holds for nearly all countries, large crosscountry differences are observed. Belgium stands out in that the labour share - at just over 70 per cent, according to OECD figures - has remained among the highest in the OECD. As elsewhere, that share has dropped but the decline has been relatively moderate.

The continued strong role for collective bargaining may be part of the explanation. Ferguson (1996), for example, finds that union decline in the US explains about 25 per cent of the dramatic increase in the wage-productivity gap. Fichtenbaum (2011) found that it might explain even a larger part of the decline in labour's share of income. The OECD (2012) shows that declines in labour shares have typically been smaller in sectors in which unions are more strongly represented.

Belgium is one of the few countries to apply automatic adjustment of wages and benefits (including pensions) to inflation. The system finds its origins in 1920 when Minister Wouters instituted a price inflation (index) measure. This happened in response to social unrest caused by post-First World War price increases. At the time only a handful of sectors applied automatic indexation. The system of automatic indexation was gradually expanded to other sectors. The procedure differs from sector to sector.

Concerns relating to wage-cost competitiveness have led consecutive governments to reform the relevant index, including a series of modifications of the basket of goods and services included. A major reform occurred in 1994 when the so-called 'health index' became the benchmark, a basket of goods that excludes unhealthy (for example, cigarettes) and environmentally harmful items (for example, petrol). The Dehaene 
government, being only too aware of the sacrosanct status of the index in Belgium, thus attempted to structurally moderate the impact of indexation while keeping the mechanism itself intact. (That initially worked, but over recent years the health index has increased more than the normal consumer price index.)

The index has acquired enormous symbolic significance in Belgium. Unilateral political steps to modify or suspend the index, which have been tried on several occasions, have invariably triggered massive unrest, and even strikes. Organisations such as the OECD and the International Monetary Fund (IMF) have for many decades tried to convince Belgian governments to abolish the index altogether, but to no avail, for the index remains inviolable. The same applies to collective bargaining. The OECD and the IMF have issued numerous recommendations to weaken the grip of collective bargaining on wage-setting, urging what is called 'decentralisation'. Such recommendations have never even made it to the political negotiating table. There remains a relatively wide, if not unanimous, consensus that automatic indexation and comprehensive wage bargaining help to maintain living standards, as well as social peace and cohesion.

Almost everybody's pay in Belgium remains determined by a collective agreement. Wage bargaining occurs in three consecutive stages. A first round of bargaining at the national level sets out essential parameters, for example, the scope for overall wage growth and minimum wage levels. Then a multitude of joint committees implement the national target at the sectoral level. A third round of bargaining sometimes takes place at the firm level, especially in larger firms. Collective agreements are generally extended by the Ministry of Labour to cover almost the entire workforce. Whether or not this happens is a matter of the legal terms of the agreement, not whether it is in the interest of the economy or of the broader population, especially those affected but not represented either by the unions or by employers' organisations.

While comprehensive collective wage bargaining remains intact, concerns about competitiveness have led governments towards a more interventionist stance on overall wage growth. The Competitiveness Law of 1989 (which was extended in 1996 and modified in 2014) institutionalised government intervention in wage-setting. A monitoring system was introduced, benchmarking wage developments in Belgium against those in main trading competitors and neighbouring countries Germany, France and the Netherlands. The weighted average of pay developments in these countries is taken as the upper margin for negotiations (wage norm), as wage increases beyond this limit trigger government intervention. It is set every two years in the IPA by the social partners, based on estimates provided by the Central Economic Council, on which the social partners sit. The social partners currently face much tighter limits in terms of what they can agree on, especially with regard to wage increases, than ten or 20 years ago. This tighter framework is due in large part to processes originating from Belgium's membership of the EU and the euro area. Paradoxically, perhaps, this has made it easier for social dialogue and collective bargaining to persist. That is, we might argue that stronger government action, in part prompted by developments at the European level, has strengthened social dialogue because face-saving agreements for all parties are easier to achieve within externally imposed bargaining limits.

In addition to wages having continued to grow, there has been no increase in wage inequality, at least as far as the data show. Belgium has just about the most compressed wage distribution among the rich countries, especially at the lower end of the distribution. The 
fact that there been no growth in low-paid employment is especially striking. According to OECD figures for 2015, less than 4 per cent of Belgian workers work for relatively low pay as the OECD defines it (OECD 2015c), compared with 9 per cent in France, 15 per cent in the Netherlands and 18 per cent in Germany. In the Netherlands and especially in Germany there appears to have been a clear rise.

Why does Belgium have so few relatively low-paid workers? Nearly all EU member states now have a national statutory minimum wage, with Germany the last big country to introduce one in 2015 (Marchal and Marx 2018). There are still some exceptions, most importantly the Scandinavian countries, and Austria and Italy.

Belgium is also an exception in that it does not have a statutory minimum wage but there is a minimum wage on which employers and trade unions agree at the national level. This minimum wage has mainly a benchmarking purpose. Effective minimum floors pay scales for the youngest, least qualified and least experienced workers - are negotiated at the sectoral level and tend to be considerably higher than the national minimum wage. Industries in which these are 20 to 30 per cent above the national minimum are not exceptional (Vandekerckhove and Van Gyes 2014).

It is disputed whether there is a downside to Belgium's high wages and the lack of relatively low-paid jobs. Employment growth has been structurally weak in Belgium. Overall, employment is far below the levels found in neighbouring countries such as Germany and the Netherlands, countries in which low-paid work is far more prevalent. Moreover, Belgium is facing employment deficits among low-skilled people and those of migrant descent, which are among the worst in Europe. In the EU28, the employment rate for those not born in the EU is about 10 percentage points lower than that of natives. In Belgium this is over 20 percentage points.

An often heard argument against high wage floors is that they come at the cost of fewer jobs. The debate on whether minimum wages destroy jobs or stifle job growth is as old as the minimum wage itself. A wealth of empirical evidence has been amassed by labour economists (Salverda and Checci 2015). The measured effects of minimum wage increases have never been very large, perhaps because increases tend to be very cautious and conservative. Research suggests that the effects may be stronger for particular subgroups; when significant negative employment effects are found, they tend to be among young people. Also, the extent to which relatively high wage floors are compatible with acceptably functioning labour markets seems to depend on contextual factors, such as workforce skill levels; countries with higher skilled workforces seem to sustain more compressed wage distributions (OECD 2015a). In that context it is relevant to note that while Belgium's (regionalised) schooling system yields good outcomes overall, the proportion of youngsters leaving school without formal qualifications remains high.

In summary, Belgium's three-stage collective-bargaining model, in combination with general extension and automatic indexation, has probably played an important role in the steady wage rises Belgian workers have enjoyed across the board. Many studies find, after all, a very strong link between the extent and strength of collective-bargaining and wage outcomes, including growth and inequality (Plasman et al. 2007; Garnero et al. 2015; Salverda and Checchi 2015; Bosch 2015). Whether and to what extent this comes at the price of weak employment growth and few job opportunities for the less skilled remains unclear, but these are real issues. However, other factors may account for Belgium's weak 
employment outcomes, to which we turn in the next section, including the issue of labour market flexibility.

\section{EMPLOYMENT: THE ROLE OF INDUSTRIAL RELATIONS IN LABOUR SHEDDING AND FLEXIBILITY}

Employment growth in Belgium has been relatively weak compared with other northern European countries. This is especially evident for the Walloon region and Brussels, as shown in Figure 3.2.

One important background factor here, as already highlighted, is that Belgium's economy has undergone major restructuring in recent decades. An early industrialiser, Belgium recorded some of the largest relative job losses in manufacturing in the OECD during the 1970s and 1980s. Belgium expanded early retirement routes in order to reduce excess labour supply and to alleviate the social consequences of structural economic adjustment; but it has proved hard to scale back these schemes. This accounts for Belgium's exceptionally low employment rate among those between the age of 55 and 64, which is 10 percentage points below the EU28 average. Mass early retirement has allowed Belgium to pursue a high productivity path. In addition, steady wage increases resulting from automatic indexation of wages, together with multi-level collective bargaining, have spurred continuous investments in labour-saving automation and innovation. The result is that Belgium has among the highest productivity levels in

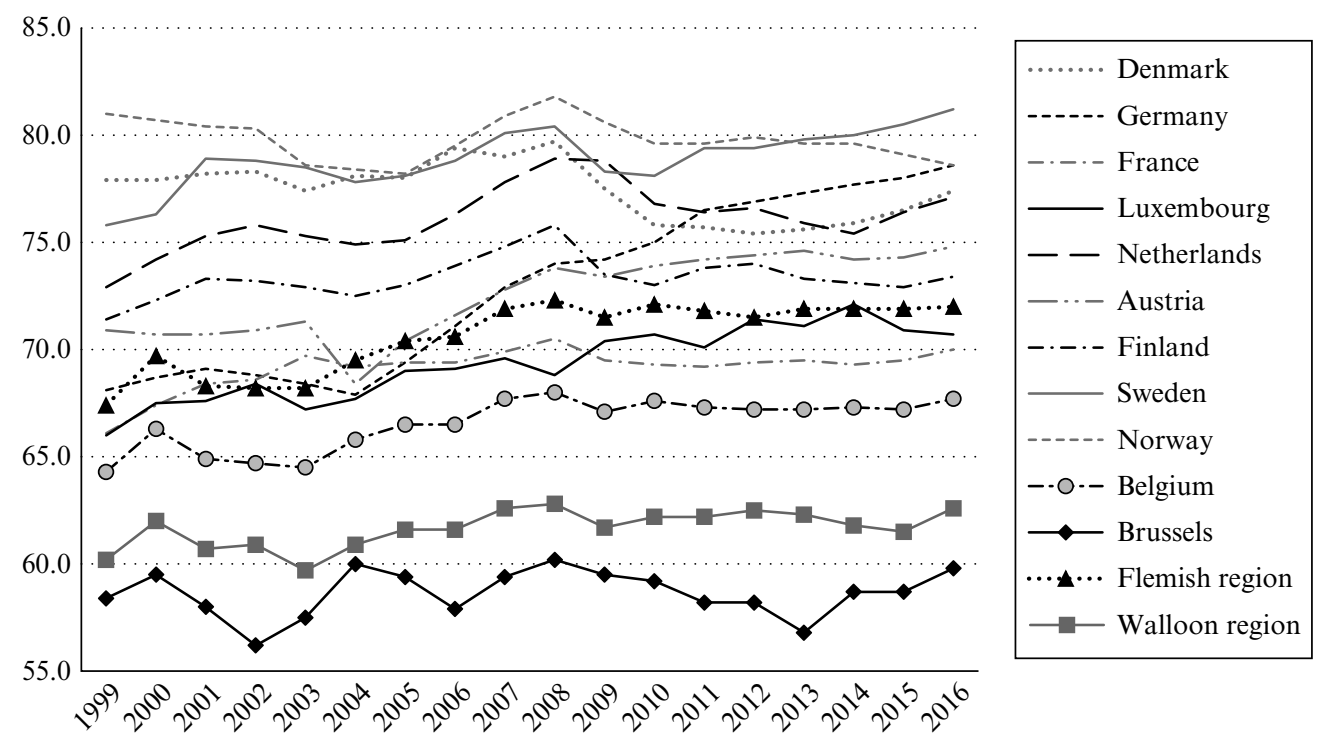

Source: Eurostat.

Figure 3.2 Employment rates, Belgium and its regions compared with selected European countries, 1999-2016 
the world, measured by output per hour worked. However, employment among older workers is low.

The strong decline in male employment has been partly compensated by increases in female employment. While labour market institutions remain breadwinner biased to some extent, provisions to support and accommodate female labour market participation have been developed, making Belgium an example of what Knijn and Kremer (1997) have called 'optional familialism'. That is, the caregiving mother is supported through, among other things, the tax system, but at the same time families are given the option of at least partially outsourcing that care.

When it comes to various forms of atypical work, Belgium is even more of an outlier. In comparative data on the extent of 'non-standard' employment, Belgium is to be found at the lower end each time, usually below the EU15 average and certainly far below its northern European neighbours. This is true if we look at the incidence of fixed-term contracts, temporary work, night work and weekend work. It is not that Belgium has actively diverged from the rest of the EU, but that many other countries have seen bigger and faster change towards more non-standard employment.

Furthermore, Belgium seems to maintain comparatively strong worker protection when it comes to working conditions. In studies that compare the extent of labour market regulation, Belgium always comes out as relatively strongly regulated. There are, for example, relatively strong legal restrictions on temporary work contracts. Zero-hours contracts are not allowed.

Such headline measures that build on what labour laws say may underestimate the real level of flexibility in the workplace. In Belgium, rules determining what can happen in the workplace are usually not set by law. Rather the government sets the framework within which (and sometimes outside which) flexibility can be exercised through collective agreement, but not through individual discretion on the part of individual employers or workers. (Some illustrations are provided in Marx and Van Cant 2018.)

Belgium's centre-right coalition government has moved recently to increase workingtime flexibility. A reform package coming into effect in 2017 - known as the Peeters Law, after the Minister of Labour - includes measures such as the annualisation of working hours, making it possible for firms to adhere to the 38 -hour week in more flexible ways. The Peeters Law also expanded the scope for firms to employ labour at night, that is, after 8 p.m. This was in response to fears that Belgium was losing out in the rapidly expanding e-commerce business, especially compared with the Netherlands and Germany.

The Peeters Law develops a new concept, of voluntary overtime, and enables workers to increase flexibility as regards their working time and place. Important measures in this respect are the establishment of a legal framework both for occasional teleworking and flexible working hours. Finally, legal opportunities to adapt working time over the life course, through various forms of (paid) leave (parental leave and medical assistance), are further extended and a system of 'career saving' has been put in place. The latter makes it possible for employees to save up additional holidays.

Despite what might be considered within the wider European context to be mild moves towards greater working-time flexibility, the Peeters Law met with significant resistance. As a consequence, the government allocated a key role to the social partners in implementing it. While the Peeters Law provides the legal framework for more working-time flexibility, its implementation is possible only through collective agreements negotiated 
by trade unions and employers at the sectoral and firm level. Any development towards more working-time flexibility that may occur as a result will thus remain negotiated.

Belgium's apparent reluctance to embrace, or even make possible, various forms of non-standard work may be deemed successful, especially in light of Principle 5 of the European Pillar, which states that 'Employment relationships that lead to precarious working conditions shall be prevented, including by prohibiting abuse of atypical contracts'.

However, under the same Principle 5 it is stated that 'in accordance with legislation and collective agreements, the necessary flexibility for employers to adapt swiftly to changes in the economic context shall be ensured'.

Asking whether Belgium meets that requirement seems legitimate. The relaxation of the rules regarding night work only occurred after it was becoming obvious that e-commerce businesses were setting up in neighbouring countries and that Belgian workers were missing out on those jobs. Similarly, we might ask whether the extent of unemployment among low-skilled people would be equally significant if greater flexibility prevailed, for example with regard to Sunday work. Unfortunately there are no reliable estimates on the extent to which limited flexibility may come at the cost of jobs.

\section{THE WELFARE STATE: STRENGTHS AND WEAKNESSES OF A SOCIAL SECURITY SYSTEM CO-GOVERNED BY THE SOCIAL PARTNERS}

By various measures Belgium has one of the most comprehensive welfare states in the European Union. Social spending levels relative to GDP are among the highest in Europe (in OECD figures Belgium takes third place behind France and Finland). Together with sizeable spending on health, education and social services (the latter two at the regional level), Belgian social spending is strongly geared towards cash transfers, with unemployment benefits being exceptionally large. Belgium spends twice the EU28 average on unemployment benefits.

Belgium's social security system is both co-funded and co-governed by trade unions and employers' organisations. This has deep historical roots. Social security arrangements in Belgium emerged from spontaneous workers' initiatives in the mid-nineteenth century. Decades of incremental expansion of various schemes culminated in the 'Social Pact' of 1944. While extending compulsory social security coverage, the pact confirmed the subsidiarity principle in the sense that non-government organisations (unions and mutual societies) remained responsible for the administration of benefits. In addition, national agencies were created for those not affiliated to such organisations. The role of the state remained, as before, mainly regulatory and complementary. A final safety net, guaranteeing minimum income protection to all, was ensured through three laws enacted in the late 1960 s and early 1970 s.

The economic downturn of the 1970s and 1980s, caused by the oil price shocks, challenged the social protection system profoundly. International observers often portray Belgium as an archetypal 'frozen' welfare state. Its complex governance structure, with a multitude of powerful veto players, is considered a major impediment to welfare reform. Cox (2012, p. 25), for example, considers Belgium 'one of the weakest cases of welfare 
state adjustment in Europe'. The author emphasises the particularly fragmented nature of Belgian politics, featuring a combination of coalition governments, federalism, corporatist consultation and linguistic division. Internal tensions are said to have dominated the policy agenda, thereby hampering the emergence of a grand narrative on welfare reform. The overall diagnosis, then, is 'policy sclerosis'.

A 'big reform' account of welfare state change does largely generate this picture. While Belgium's northern neighbour, the Netherlands, successfully undertook major social security and labour market reforms, Belgium did not do so.

However, the absence of dramatic policy overhauls has far from implied stasis. A number of analyses of the Belgian case have focused on the gradual transformation of its welfare state. Clegg (2007), for example, compares changes in unemployment policy since the 1980s in Belgium, France, Germany and the Netherlands. Only the Netherlands has enacted more fundamental reforms through law. However, policies have changed considerably everywhere, albeit more incrementally. There can be no doubt that the Belgian scheme remains a notable outlier. Unlike in the majority of countries, benefit entitlement in Belgium is, in principle, unlimited in time, a feature that has long been criticised by the OECD and the IMF in their periodic reviews of Belgium.

Accounts of inertia, as exemplified by Cox (2012), are in stark contrast, however, to the experiences of key national witnesses, who point to a frantic pace of change and a sprawl of initiatives (Rijksdienst voor Arbeidsvoorziening [RVA] 2010).

The stark discrepancy between the perception of international observers who look at Belgium from afar and those who know the system from the inside is interesting. It is owing to the nature of institutional change in a social corporatist system such as Belgium's. While it may be true that big-step change is difficult to enact in a system with so many veto players, there are more subtle adaptation mechanisms.

As a consequence of the multiple functions the unemployment insurance system has taken on, a large number of people of working age receive some kind of unemployment insurance benefit. At the peak of the recent economic crisis more than 1.3 million people were receiving unemployment benefit, roughly equal to one person receiving a benefit for every four persons working, although there is some overlap, as in the case of workers receiving short-time compensation benefits.

The massive rise in the number of people receiving some type of unemployment insurance benefit cannot be seen separately from the unions' role in the payment of unemployment benefits. The added services offered by the unions provide a clear and substantial incentive to become or remain a union member. Van Rie et al. (2011) show that the profile of union members closely matches such selective incentives. The unions have strongly resisted attempts to scale back unemployment insurance benefit, whether through the imposition of time limits or the tightening of age and other requirements for early retirement, while they have supported the proliferation of other functions (for example, early retirement, career interruption and working-time reduction compensation) the system has taken on. Many of these functions have turned out to be beneficial, such as the stabilising role of the short-time compensation scheme during the crisis or the positive impact of career interruption benefits on work-life balance. However, the continued rise in the number of people receiving benefits has come at a price in a context in which financial resources are not unlimited. As the number of beneficiaries rose, benefit levels became less generous and less adequate in providing protection against poverty. 
While still enjoying a comparatively low poverty rate, Belgium has been slipping down the rankings during the past decade and does not seem able to drive back poverty. At-risk-of-poverty rates of people living in jobless households, who are for that reason most reliant on the adequacy of transfer incomes, are extremely high (58 per cent in 2015). There is a growing income gap between those who receive income from work and those who rely mainly on income replacement benefits. While Belgium has a system (indexation) that is designed to safeguard the purchasing power of both benefits and wages, the latter have clearly outperformed the former. All social minima have eroded relative to overall living standards. The reason is in part structural. As dual earnership became the norm and drove up overall living standards, individuals or households relying on a single benefit (or a single-wage earner for that matter) inevitably fell behind. There have been repeated, beyond cost-of-living increases, but benefits often fall well short of poverty risk thresholds.

In summary, Belgium's strongly developed social security system and broader welfare state is arguably due mainly to the role of the social partners as initiators, funders and governors. The role of the social partners is strongly stabilising, conferring robustness on a system that, if under direct political control, might be more vulnerable to cutbacks. A critique often levelled against systems such as Belgium's is that they are inert and fail to adapt to new social needs and new social risks, as well as to the changing nature of traditional social risks. In the Belgian case, there has been more change than can be seen by the casual or distant observer.

The empirical evidence strongly contradicts an account of stasis. However, decades of gradual and technical change have also been associated with policy irrationalities and incoherence. The authorities have tended to handle the ambiguities and distributional implications of unemployment indirectly. Many measures and exemptions were introduced, but very few were abolished. Instead, governments preferred retrenchment by making them less generous, often gradually so (for example, part-time unemployment). This approach has cumulated in an innovative but opaque mix of measures, the distributional consequences of which are often unclear. It is important to note that since the mid-2000s, governments have implemented a number of fundamental changes to regular unemployment insurance, including stricter monitoring of availability for work. The regressivity of benefit levels has been strengthened over time. These are now framed as measures to increase the sustainability and coherence of the system and reduce moral hazard. These changes are controversial, not least among trade unionists because they are seen as punishing the unemployed. It remains to be seen what the significance of these developments will be over the longer term.

\section{CASE STUDY: AN IN-DEPTH LOOK AT BELGIUM AND THE NETHERLANDS WITH A FOCUS ON GENERAL WELFARE REFORM AND WAGES}

\subsection{Why the Netherlands?}

As signatories to the Treaty of Rome, Belgium and the Netherlands were founding members of the EU and have been at the very heart of the European project ever since. 
The countries share many similarities and thus represent excellent cases for a comparative study of the issues addressed in this book: the role of industrial relations in processes of upward social and economic convergence. First, Belgium and the Netherlands are small, open economies in the middle of Europe that share a tradition of social partnership in the areas of collective bargaining and social insurance administration. Employers and workers are well organised and collective bargaining occurs predominantly at the sectoral level.

However, the two countries are distinct in terms of the institutional frameworks of the political system within which their welfare states and industrial-relations systems are embedded, suggesting possible explanatory routes for divergent outcomes. Compared with the Netherlands, Belgium's complex and multi-layered governance structure has decisively constrained the scope of government intervention, not only in wage bargaining but also in a host of other social and economic policy areas, such as economic and trade policy, labour law, social policy and social security. Social partnership is also more fragmented and on both sides more competitive, making it difficult to establish and enact broad corporatist social pacts. There are multiple trade unions, within which regional and sectoral differences are important. As a consequence, the mechanisms through which Belgian governments have pushed for social policy reform have tended to be more informal and subtle than in the Netherlands. A major factor here is that large parts of Belgium's welfare state are not codified in law, requiring parliamentary approval for amendments. Instead, much of it is regulated by Royal Decrees, which are far more readily amendable by ministers. In the Netherlands, most aspects of social policy and social security are codified in law, so that changes require parliamentary debate and approval. This makes it harder to enact changes that are not easily perceptible to outsiders.

Both countries were facing very similar plights in the early 1980s: weak growth, high unemployment and growing benefit dependency.

In the Netherlands, the Wassenaar agreement of 1982 ushered in a period of vibrant corporatism and negotiated social reform in the Netherlands in the 1980s and early 1990s. In that agreement, the unions accepted protracted real-wage restraint in exchange for a so-called 'cost-neutral' reduction of working hours and job sharing. The main figure behind the Wassenaar agreement was Wim Kok, then leader of the main trade union confederation, FNV. He would later become prime minister of a coalition with the centre-right liberal party that would make 'Jobs, jobs and jobs' paramount in the 1990s.

Around the same time, faced with the same problems of weak growth and weak perceived international competitiveness Belgium resorted to a devaluation of the Belgian franc. This occurred because, relative to the Netherlands, Belgian trade unions and employers remained stuck in a condition of corporatist quasi-immobilism. Belgian trade unions never accepted that wage restraint might be necessary for economic recovery and job growth. In part, this reflected the continued strength of the Belgian unions compared with their Dutch counterparts. The Belgian government ultimately had to impose wage restraint from above. In sharp contrast to the Dutch experience, the Belgian welfare state proved unable to reverse the cycle of welfare without work. Belgium has proved to be all but the archetypal 'frozen' welfare state but the changes made have also been mostly defensive, in order to cope with the inescapable pressures imposed by external circumstances: first massive job losses, then the need for budgetary restraint (as a member of the European Monetary Union). 


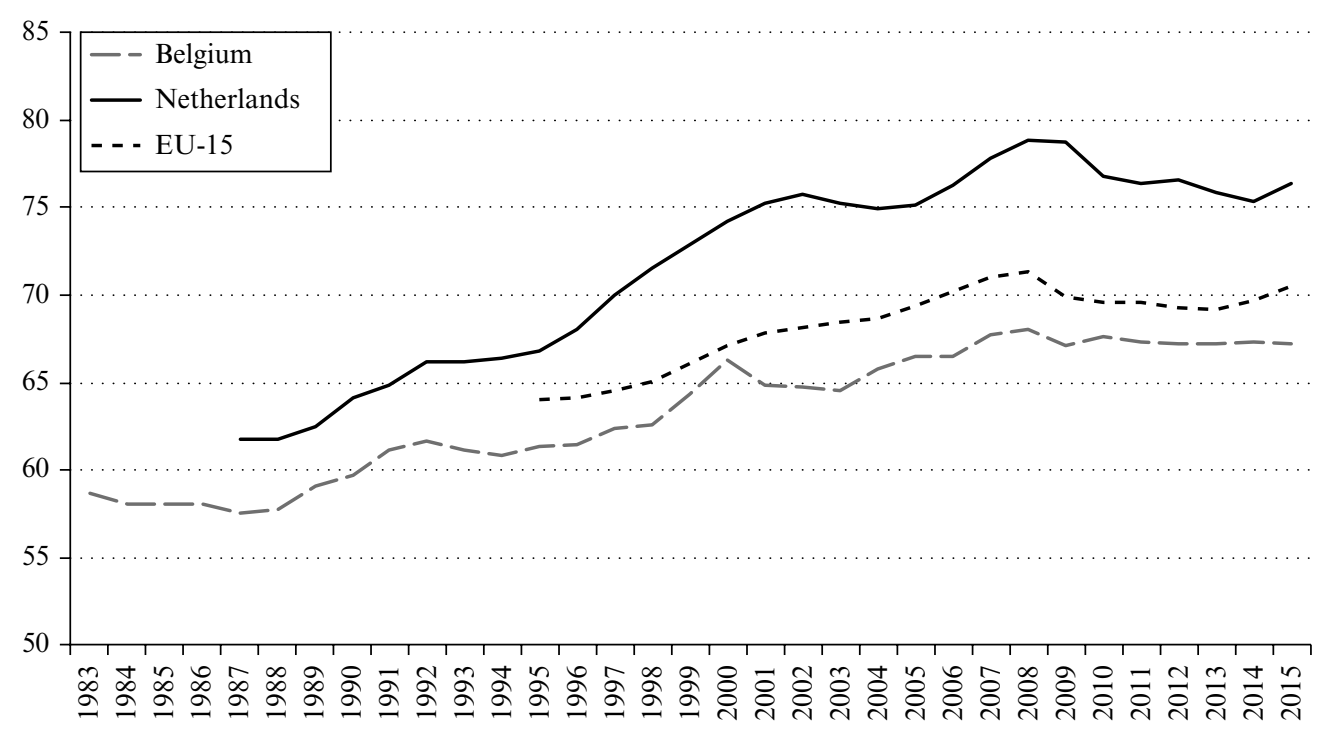

Source: Eurostat.

Figure 3.3 Employment rates, people aged 20-64, Belgium and the Netherlands, 1983-2015

It is clear that both countries have pursued very divergent trajectories when it comes to such issues as employment (Figure 3.3), wage growth (overall and, especially, at the lower end), contract and working-hours flexibility, and a host of other outcomes. Trends at the level of overall living standards, as measured on the basis of household disposable income adjusted for household size, are far less divergent, demonstrating that rising overall living standards are achievable through widely divergent routes. In the case of Belgium, wage growth has played a larger part in this than employment growth.

\subsection{The Wassenaar Agreement Concluded by the Social Partners When Belgium Devalued in the Absence of Such an Agreement}

The depth of the 1981-82 recession in the wake of the oil crises of the 1970s catalysed path-breaking change in the Netherlands, beginning with a government-imposed suspension of wage indexation, a squeeze on the minimum wage and a lowering of social benefits. The elections in 1982 brought to power an austerity coalition of the Christian Democrats and centre-right liberals. After a decade of failed tripartite attempts based on Keynesian premises, the Dutch social partners crowned the new austerity coalition's entry into office with a bipartite social pact on 24 November 1982, known as the Wassenaar agreement, named after the suburb of The Hague where the agreement was prepared. The agreement ushered in a period of vibrant corporatism and negotiated social reform in the 1980s and early 1990s (Visser and Hemerijck 1997). The unions accepted realwage restraint in exchange for a reduction of working hours and job sharing. This new Dutch corporatism of the 1980 s proved fairly robust, although it was certainly not free 
of conflict. At the turn of the 1990s, German reunification boosted Dutch growth, but high interest rates soon dampened economic activity, leading to a reversal of employment gains. In another attempt to stave off government intervention, the social partners signed a multi-year agreement, the so-called 'New Course' accord, in December 1993 (Hemerijck and Marx 2010), which ushered in a trajectory of organised decentralisation in Dutch employment relations.

During the 1990s the Dutch moved to curtail easy exit and activate the non-active in a labour market based on flexicurity. There was a fundamental overhaul in the administrative and incentive structures of social security. Labour market flexibility became an integral part of the new policy mix and enjoyed significant support from the social partners. Together with the incremental individualisation of the tax system, flexicurity legislation contributed to the normalisation of part-time employment. This was accompanied by the introduction of more market-orientated approaches in the management of the social security system where the state adopted a fairly aggressive posture, both privatising and nationalising portions of the welfare state, in particular the regulation of new claimants. Also, competition was increased in the provision of social security and health care.

The reforms in the 2000s affecting unemployment and social assistance programmes, as well as the introduction of the new disability benefit programme (WIA), were part of even more intensified activation efforts. The overall trend was towards increased employment conditionality, increased activation, more stringent targeting and reduced generosity. Work came to be seen as the key route for attaining personal welfare and social cohesion, as well as for the sustainability of a generous welfare state.

The Dutch trajectory over recent decades is vastly different from the Belgian trajectory in a host of dimensions. Space limits preclude a detailed discussion of all aspects here. I focus a bit more on wages, a key domain with strikingly divergent outcomes, despite similar institutions. Both countries retain extensive collective bargaining, with the centre of gravity at the sectoral level, and the resulting collective agreements are generally extended.

As mentioned previously, in terms of overall wage growth, Belgium and the Netherlands have followed entirely different trajectories, but this is also true when it comes to the lowest wages. While Belgium maintains a very compressed wage distribution and just about the smallest segment of relatively low-paid work in the rich world, the Netherlands has seen an expansion of low-paid work (along with non-standard work) (Figure 3.4).

The social partners first agreed in 1964 that national collective agreements should respect the national statutory minimum wage. The minimum wage was given central importance in the Dutch system of social security in the mid-1970s, when net minimum benefits equal to the net minimum wage were set. The minimum wage had a direct and significant impact on public finances. The minimum wage was supposed to automatically follow the general evolution of wages, but policy measures have made it lag behind earnings since the early 1980s. It was nominally lowered or frozen on several occasions. In 1992 a new law was passed that gave the government the authority to freeze or lower the minimum wage in case of an extreme wage increase or an increase in the number of social-security recipients that would necessitate an upsurge of social contributions or taxes. Relative to its 1979 value, today's adult minimum wage has lost more than 20 per cent of its purchasing power - lagging almost as far behind negotiated wages and 36 per cent below actual hourly earnings (De Beer et al. 2017). 


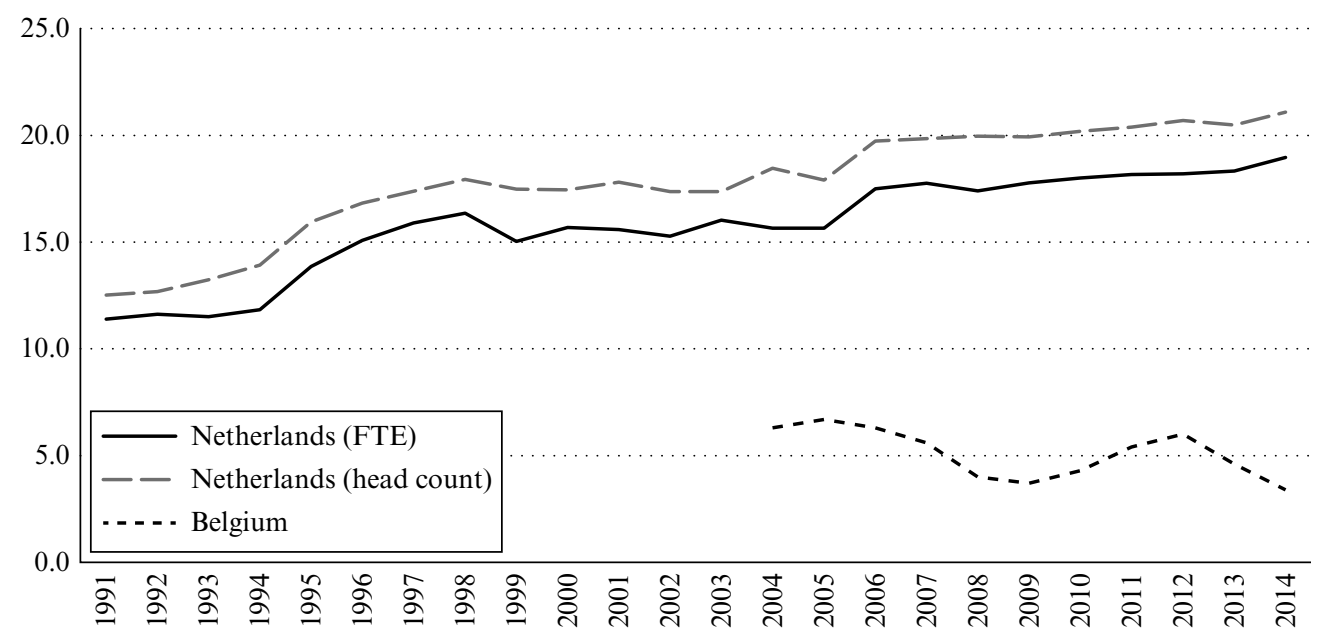

Sources: For Belgium: OECD; for the Netherlands: Wiemer Salverda.

Figure 3.4 Low pay trends, Belgium and the Netherlands, 1991-2014

From the mid-1990s, the government pressed the social partners to bring the lowest pay scales down to the minimum wage. It was Social Democrat Minister of Labour, Melkert, who first threatened to refuse to declare collective agreements generally binding unless the lowest pay scales actually moved towards the minimum wage. The coverage of collective agreements providing for scales below 105 per cent of the minimum wage increased quite significantly. The effect was in part mitigated by the fact that few workers actually work for the lowest theoretical pay scales.

The wages of workers at lower levels of (actual) pay have nevertheless grown less than those of higher earners. Over the period considered, workers in the first decile of the wage distribution did not see their real wages increase, but those earning the least saw their wages decline, in line with the evolution of the minimum wage. Low-wage employment (defined as jobs paying less than two-thirds of the median hourly wage) grew significantly, from 11 per cent of all hours worked in 1979 to 16 per cent in the mid2000s. This was particularly applicable to part-time workers, whose low-wage incidence increased from 17 to 27 per cent, while among full-time workers it remained virtually stable at 10 per cent. Part-time employment grew considerably - part-time workers now make up 70 per cent of all low-paid workers, as against 24 per cent in 1979 - increasing the incidence of low pay (Van Klaaveren et al. 2009).

\subsection{Do Different Industrial Relations Paths Help to Explain Different Trajectories?}

Why did the Dutch unions go along with this path of continued wage restraint and why did they accede to wage erosion at the lower end of the distribution? In the early 1980s both countries were facing a similar plight of welfare without work, with seeming unstoppable increases in the numbers of people of working age - often in the prime of their life - dependent on benefits. 
In the Dutch case, the Wassenaar agreement, in retrospect, generated a benevolent positive feedback dynamic. The original objective of the Wassenaar agreement was to restore Dutch competitiveness with the cooperation of the unions; wage restraint in exchange for working-time reduction. But the Wassenaar agreement proved more successful than that, no doubt helped by a general economic recovery. This initiated a positive feedback dynamic of enhanced trust and policy learning, which over time also allowed for more path-breaking social policy innovation and experimentation. The Netherlands went down the path of labour market flexibility, social insurance reform and activation in a much more radical way than Belgium.

Owing to the depth of the initial crisis and lack of trust and cooperation between the social partners, positive feedback effects remained absent in Belgium. Perhaps the Belgian context was an unlikely one for a Wassenaar-style pact to emerge. Unlike the Netherlands, Belgium was characterised by deep-cutting internal divisions along linguistic and ideological lines, resulting in a far more fragmented and conflict-ridden political system than the Netherlands. The unions, too, have remained unitary in name, but in reality major divisions have always existed between the Flemish- and French-speaking wings. Also, the real power lies with the sectoral organisations.

In Belgium the social partners never came close to a Wassenaar-type pact. It was left to the government to take responsibility for restoring economic competitiveness, which it was able to do by resorting to a major currency devaluation in 1981. Whereas wage moderation required sustained discipline on the part of the social partners, the devaluation effectively offered a bailout to the social partners to continue in their pursuit of wage gains.

This brings us to a second major difference, the role of the state. In the Netherlands, where the state is unitary, authorities have at times been able to intervene more directly than have their Belgian counterparts. The government has had the power to secure moderate wage agreements, increase labour market flexibility, curtail moral hazard in the social security system and redirect pension modernisation by way of a shadow hierarchy, involving the state's implicit or explicit threats to intervene in the event of the social partners' failure to act.

This brings us to a third major difference: the unions simply remain more powerful in Belgium, as is evidenced by high and stable membership rates. While the Dutch social partners have seen their involvement in social insurance administration severely restricted, the trade unions in Belgium continue to co-administer unemployment benefits, and receive substantial funding for doing so. This contributes to their continued strength and at times formidable mobilising efforts.

\subsection{Conclusion}

The comparison between Belgium and the Netherlands is particularly informative in the context of this book. The countries share many economic and institutional similarities, including strong social dialogue and collective-bargaining institutions and practices. The role of the (central) state has become considerably stronger in the case of the Netherlands, while in Belgium the social partners maintain a high degree of power and representative legitimacy, despite increased state intervention in certain areas, or attempts to that effect. This case study has focused on general welfare reforms and on wage (structure) 
developments. While the Netherlands has seen many structural reforms and sustained wage moderation, this has not occurred in Belgium, demonstrating that economic and institutional settings that are broadly similar still allow for widely divergent trajectories.

\section{CONCLUSIONS}

The European Pillar of Social Rights, launched in 2017, seeks to promote upward social convergence across the EU. As part of the same drive towards furthering Europe's social dimension, the European Commission has also started calling for more substantial involvement of the social partners and a strengthening of their role.

In this context, Belgium represents a particularly interesting case in that it retains an exceptionally extensive and resilient social concertation model. Belgium's social partners maintain a central role in many aspects of socio-economic policy-making and beyond. In addition to the issues on which they negotiate and conclude collective agreements, they also wield significant influence in shaping social and economic policy through their institutionalised advisory and governance roles. In this chapter I have tried to gauge how this matters for the trajectory that Belgium has followed, in both economic and social terms.

Looking at economic outcomes first, we find there has been less of a divergence in Belgium between conventional measures of economic affluence, such as GDP per capita, and actual household living standards. That is, the benefits of economic growth, including those generated by long-standing single-market membership, appear to have been more equitably spread than in many other rich economies.

This chapter has demonstrated that strong real-wage growth across the board has been an important factor here, in addition to the rise of dual-earner households and extensive redistributive efforts, through both benefits and progressive taxes.

Social corporatist institutions such as comprehensive wage bargaining, general extension of collective agreements and automatic indexation are almost certainly key determinants of Belgium's atypical trajectory in terms of wage growth and stable income inequality. Automatic indexation of wages and benefits, a feature of the Belgian system fiercely defended by the unions, has also helped to maintain benefits.

Belgium spends significantly more on unemployment benefits than other countries, in part because unemployment benefits are not limited in time and the role of social assistance remains more residual. In addition, the unemployment insurance system has taken on many other functions, including early retirement, career interruption and workingtime reduction compensation. This is probably owing, at least in part, to the trade unions maintaining a strong role in the governance and administration of the system.

Belgium's social corporatist model has no doubt contributed to its exceptional rising living standards across the board. However, access to a good life remains unequal. The major fault-line in Belgium is not between high- and low-waged workers, or between precarious and non-precarious workers, but between those with a job and those without a job.

Belgium has just about the highest share of working age people living in a household in which nobody has a job. Such households often live in financial poverty. The employment chances of low-skilled people and migrants are comparatively low. For a country with a comparatively low level of income inequality and a comparatively high level of social 
spending, Belgium has a strikingly high share of the population living in relative income poverty. Belgium's overall poverty rate, measured by the EU's relative at-risk-of-poverty threshold, has remained at around 15 per cent and child poverty close to 20 per cent. That is significantly higher than, for example, in the Netherlands, a country that has higher overall income inequality and a similar level of social protection spending.

This chapter has looked at how industrial relations have affected convergence outcomes in Belgium compared with its northern neighbour, the Netherlands. Both are small, open economies with a strong tradition of social partnership. Employers and workers are well organised and collective bargaining occurs predominantly at the sectoral level. Yet Belgium and the Netherlands have followed distinctly different trajectories, despite these similarities. The social partners in the Netherlands have embraced wage moderation, labour market flexibility, marketisation of certain aspects of the welfare state and intensified activation. Employment growth has been very strong in the Netherlands, albeit largely in the form of atypical employment, especially part-time work. Some argue that the proliferation of flexible and precarious, as well as low-paid, employment has gone too far. Belgium, by contrast, has pursued a continued wage growth path and the social partners have remained much more reluctant when it comes to adopting various forms of atypical employment. Employment growth has been much weaker in Belgium but, strikingly, about the same relative amount of aggregated working time is performed in Belgium and in the Netherlands, despite the latter now having a much higher share of the working-age population in employment. Nevertheless, when it comes to household living standards, or the perceived quality of work and life, trends are far less divergent, demonstrating that there can be multiple routes to upward social convergence. That is an important lesson in an EU where subsidiarity remains a core principle in relation to social outcomes.

\section{REFERENCES}

Anderson, K.M., S. Kuipers, I. Schulze and W. van den Nouland (2007), 'Belgium: linguistic veto players and pension reform', in E.M. Immergut, K.M. Anderson and I. Schulze (eds), The Handbook of West European Pension Politics, Oxford: Oxford University Press.

Biatour, B. and C. Kegels (2008), 'Growth and productivity in Belgium', Working Paper No. 17-08, Federal Planning Bureau, Brussels.

Bosch, G. (2015), 'Shrinking collective bargaining coverage, increasing income inequality: a comparison of five EU countries', International Labour Review, 154 (1), 57-66.

Cassiers, I., P. De Villé and P. Solar (1996), 'Economic growth in post-war Belgium', in N. Crafts and G. Tonioli (eds), Economic Growth in Europe since 1945, Cambridge: Cambridge University Press, pp. 173-209.

Clegg, D. (2007), 'Continental drift: on unemployment policy change in Bismarckian welfare states', Social Policy \& Administration, 41 (6), 597-617.

Cox, R.H. (2012), 'How globalization and the European Union are changing European welfare states', in G.B. Cohen, B.W. Ansell, R.H. Cox and J. Gingrich (eds), Social Policy in the Smaller European Union States, New York: Berghahn Books, pp. 17-32.

De Beer, P., W. Been and W. Salverda (2017), 'The interplay between the minimum wage and collective bargaining in the Netherlands - a case study of three sectors', AIAS Working Paper No. 173, Amsterdam Institute for Advanced Labour Studies, University of Amsterdam.

Ferguson, W. (1996), 'Explaining the rising wage-productivity gap of the 1980s: effects of declining employment and unionization', Review of Radical Political Economics, 28 (2), 77-115. 
Fichtenbaum, R. (2011), 'Do unions affect labor's share of income: evidence using panel data', American Journal of Economics and Sociology, 70 (3), 784-810.

Garnero, A., S. Kampelmann and F. Rycx (2015), 'Minimum wage systems and earnings inequalities: does institutional diversity matter?', European Journal of Industrial Relations, 21 (2), 115-30.

Hemerijck, A. and I. Marx (2010), 'Continental welfare at a crossroads: the choice between activation and minimum income protection in Belgium and the Netherlands', in B. Palier (ed.), A Long Goodbye to Bismarck? The Politics of Welfare Reforms in Continental Europe, Amsterdam: Amsterdam University Press, pp. 129-55.

International Labour Organization (1956), 'Social aspects of European economic co-operation. Report by a group of experts (summary)', International Labour Review, 74 (2), 99-123.

Knijn, T. and M. Kremer (1997), 'Gender and the caring dimension of welfare states: toward inclusive citizenship', Social Politics: International Studies in Gender, State \& Society, 4 (3), 328-61.

Kuypers, S. and I. Marx (2016), 'Social concertation and middle-class stability in Belgium', in D. Vaughan-Whitehead (ed.), Europe's Disappearing Middle Class? Evidence from the World of Work, Cheltenham, UK and Northampton, MA, USA: Edward Elgar and Geneva: ILO, pp. 112-59.

Marchal, S. and I. Marx (2018), 'Stemming the tide: what have EU countries and the US done to support low-wage workers in an era of downward wage pressures?', Journal of European Social Policy, 28 (1), 18-33.

Marx, I. and L. Van Cant (2018), 'Belgium: is robust social concentration providing a buffer against growing inequality?', in D. Vaughan-Whitehead (ed.), Reducing Inequalities in Europe: How Industrial Relations and Labour Policies Can Close the Gap, Cheltenham, UK and Northampton, MA, USA: Edward Elgar and Geneva: ILO, pp. 116-67.

Marx, I. and G. Verbist (2018), 'Belgium: the poster child for inclusive growth?', in B. Nolan (ed.), Inequality and Inclusive Growth in Rich Countries Shared Challenges and Contrasting Fortunes, Oxford: Oxford University Press.

Nolan, B. (ed.) (2018), Inequality and Inclusive Growth in Rich Countries Shared Challenges and Contrasting Fortunes, Oxford: Oxford University Press.

Nolan, B., M. Roser and S. Thewissen (2018), Median household income and GDP', in B. Nolan (ed.), Generating Prosperity for Working Families in Affluent Countries, Oxford: Oxford University Press, ch.4.

Nolan, B., W. Salverda, D. Checchi, I. Marx, A. McKnight, I.G. Tóth, et al. (eds) (2014), Changing Inequalities and Societal Impacts in Rich Countries: Thirty Countries' Experiences, Oxford: Oxford University Press.

Organisation for Economic Co-operation and Development (OECD) (1997), Employment Outlook, Paris: OECD.

Organisation for Economic Co-operation and Development (OECD) (2008), Growing Unequal: Income Distribution and Poverty in OECD Countries, Paris: OECD.

Organisation for Economic Co-operation and Development (OECD) (2011), Divided We Stand: Why Inequality Keeps Rising, Paris: OECD.

Organisation for Economic Co-operation and Development (OECD) (2012), Settling In: OECD Indicators of Immigrant Integration 2012, Paris: OECD.

Organisation for Economic Co-operation and Development (OECD) (2015a), Employment Outlook 2015, Paris: OECD.

Organisation for Economic Co-operation and Development (OECD) (2015b), In It Together: Why Less Inequality Benefits All, Paris: OECD.

Organisation for Economic Co-operation and Development (OECD) (2015c), Economic Survey of Belgium, Paris: OECD.

Plasman, R., M. Rusinek and F. Rycx (2007), 'Wages and the bargaining regime under multi-level bargaining: Belgium, Denmark and Spain', European Journal of Industrial Relations, 13 (2), 161-80.

Rijksdienst voor Arbeidsvoorziening (RVA) (2010), 75 Jaar RVA. Een Blik Op Verleden, Heden en Toekomst, Brussels: RVA. 
Salverda, W. and D. Checchi (2015), 'Labor market institutions and the dispersion of wage earnings', in A.B. Atkinson and F. Bourguignon (eds), Handbook of Income Distribution, vol. 2B, Amsterdam: Elsevier, pp. 1535-727.

Van Klaveren, M., W. Salverda and K. Tijdens (2009), 'Retail jobs in the Netherlands: low pay in a context of long-term wage moderation', International Labour Review, 148 (4), 413-38.

Van Rie, T., I. Marx and J. Horemans (2011), 'Ghent revisited: unemployment insurance and union membership in Belgium and the Nordic countries', European Journal of Industrial Relations, 17 (2), 125-39.

Vandekerckhove, S. and G. Van Gyes (2014), Minimum Wages in Belgium: A Maze, or Amazing? Brussels: European Commission.

Visser, J. and A. Hemerijck (1997), A Dutch 'Miracle': Job Growth, Welfare Reform and Corporatism in the Netherlands, Amsterdam: Amsterdam University Press. 